UDK $577.1: 61$

ISSN 1452-8258

J Med Biochem 40: 327-334, 2021

\title{
ANTI-SPIKE S1 IGA, ANTI-SPIKE TRIMERIC IGG, AND ANTI-SPIKE RBD IGG RESPONSE AFTER BNT162B2 COVID-19 MRNA VACCINATION IN HEALTHCARE WORKERS
}

\author{
ANTI-SPIKE S1 IG, ANTI-SPAKE TRIMERINI IGG, I ANTI-SPIKE RBS IGG KOJI SE JAVLJAU \\ NAKON BNT162B23 COVD-19 MRNA VAKCINACIJE ZDRAVSTVENIH RADNIKA
}

\author{
Gian Luca Salvagno 1,2, Brandon M. Henry3, Giovanni di Piazza4, Laura Pighi'1,2, \\ Simone De Nitto ${ }^{1,2}$, Damiano Bragantini ${ }^{5}$, Gian Luca Gianfilippi ${ }^{4}$, Giuseppe Lippi ${ }^{1}$ \\ ${ }^{1}$ Section of Clinical Biochemistry, University of Verona, Verona, Italy \\ ${ }^{2}$ Service of Laboratory Medicine, Pederzoli Hospital, Peschiera del Garda, Italy \\ ${ }^{3}$ The Heart Institute, Cincinnati Children's Hospital Medical Center, Cincinnati, OH, USA \\ ${ }^{4}$ Medical Direction, Pederzoli Hospital, Peschiera del Garda, Italy \\ 5 Infectious Diseases Unit, Pederzoli Hospital, Peschiera del Garda, Italy
}

\section{Summary}

Background: Most studies on immune response after coronavirus disease 2019 (COVID-19) vaccination focused on serum $\lg G$ antibodies and cell-mediated immunity, discounting the role of anti-SARS-CoV-2 neutralizing IgA antibodies in preventing viral infection. This study was aimed to quantify serum $\operatorname{lgG}$ and $\lg A$ neutralizing antibodies after mRNA COVID-19 vaccination in baseline SARS-CoV-2 seronegative healthcare workers.

Methods: The study population consisted of 181 SARSCoV-2 seronegative healthcare workers (median age 42 years, $59.7 \%$ women), receiving two doses of Pfizer COVID-19 vaccine BNT162b2 (Comirnaty). Serum samples were collected before receiving the first vaccine dose, 21 days (before the second vaccine dose) and 50 days afterwards. We then measured anti-spike trimeric $\lg G$ (Liaison $\mathrm{XL}$, DiaSorin), anti-spike receptor binding domain (RBD) lgG (Access 2, Beckman Coulter) and anti-spike S1 subunit IgA (ELISA, Euroimmun). Results were presented as median and interquartile range (IQR).

\begin{abstract}
Kratak sadržaj
Uvod: Većina studija imunog odgovora nakon oboljenja korona virusom (COVID-19) i vakcinacije zasniva se na serumskim lgG antitelima i ćelijski posredovanom imunitetu, ne vodeći računa o anti-SARS-CoV-2 neutralizujućim lgA antitelima i sprečavanju virusne infekcije. Ovo izučavanje ima za cilj da kvantifikuje serumski lgG i lgA neutralizujućih antitela nakon mRNA COVID-19 vakcinacije kod SARSCOV-2 seronegativnih zdravstvenih radnika.

Metode: Populaciju za izučavanje činilo je 181 SARS-COV-2 seronegativna zdravstvena radnika (oko 42 godine starosti, $59,76 \%$ su bile žene) koji su primili dve doze Pfizer COVID10 vakcinu BNT162b2 (Comirnaty). Uzorci seruma su uzeti pre prijema prve vakcine, 21 dan pre druge doze vakcine i 50 dana nakon druge doze vakcine. Mereni su anti-spike trimerik lgG (Liaison XL, DiaSorin), anti-spike receptor vezujući domen (RBD), IgG (Access 2, Beckman Cooulter) i antispike $\mathrm{S} 1$ subjedinica IgA (ELISA, Euroimmun). Rezultati su prikazani kako medijana i interkvartilna oblast (IQR).
\end{abstract}

\footnotetext{
Address for correspondence:

Prof. Giuseppe Lippi

Section of Clinical Biochemistry

University Hospital of Verona

Piazzale L.A. Scuro, 10

37134 Verona - Italy

Tel. 0039-045-8122970

Fax. 0039-045-8124308

e-mail: giuseppe.lippi@univr.it
} 
Results: Vaccine administration elicited all anti-SARS-CoV2 antibodies measured. Thirty days after the second vaccine dose, $100 \%$ positivization occurred for anti-spike trimeric $\lg G$ and anti-spike RBD lgG, whilst $1.7 \%$ subjects remained anti-spike S1 IgA negative. The overall increase of antibodies level ratio over baseline after the second vaccine dose was 576.1 (IQR, 360.7-867.8) for anti-spike trimeric lgG, 1426.0 (IQR, 742.0-2698.6) for anti-spike RBD IgG, and 20.2 (IQR, 12.5-32.1) for anti-spike S1 IgA. Significant inverse association was found between age and overall increase of anti-spike trimeric $\lg G(r=-0.24$; $p=0.001)$ and anti-spike S1 $\operatorname{lgA}(r=-0.16 ; p=0.028)$, but not with anti-spike RBD $\lg G(r=-0.05 ; p=0.497)$.

Conclusions: mRNA COVID-19 vaccination elicits sustained serum levels of anti-spike trimeric lgG and anti-spike RBD $\lg G$, while also modestly but significantly increasing those of anti-spike S1 IgA.

Keywords: COVID-19, vaccination, immune response, antibodies, IgA

\section{Introduction}

After the first case of severe acute respiratory syndrome coronavirus disease 2019 (SARS-CoV-2) infection has been described in the Chinese city of Wuhan, at the end of the 2019 (1), the severe and multifaceted infectious disease caused by this novel coronavirus spread across the world, achieving pandemic dimensions. SARS-CoV-2 mainly spreads with two different mechanisms, encompassing airborne transmission through inhalation of infected droplets or aerosols, as well as by direct contact with infected objects or surfaces followed by transportation of viable viral particles to eyes, nose or mouth, where they penetrate the host cells through biding to its natural receptor, the angiotensin converting enzyme 2 (ACE-2) (2). According to these paradigmatic modes of transmission, many mitigation measures have been endorsed to prevent or limit the risk of SARS-CoV-2 contagion, such as face covering, hand hygiene, social distancing, contact tracing and quarantine (3). Though these measures, both alone and in combination, were proven effective to mitigate the community spread of SARS-CoV-2, the burden of patients with coronavirus disease 2019 (COVID-19) remains dramatically high worldwide (4), such that alternative and even more radical strategies should be envisaged.

According to the World Health Organization (WHO), vaccination is considered a simple, secure and effective means for safeguarding the population against the risk of contracting infectious diseases or developing severe forms of infection-related illness (5). In practice, vaccine administration uses the host natural defenses (i.e., the immune system) for developing resistance against a specific microorganism though development of three principal mechanisms, i.e., production of specific antibodies (humoral immunity), training of immune cells to produce immune
Rezultati: Vakcina je proizvela sva anti-SARS-CoV-2 antitela koja su merena. Trideset dana nakon davanja doze vakcine javila se $100 \%$ pozitivnost na anti-spike trimerni IGG i antispike RBS lgG, dok je 1,7\% osoba bilo negativno na antispike S1 IgA. Ukupno povećanje nivoa antitela iznad bazične granice nakon druge vakcine bila je 576,1 (IQR, 360,7867,8) za anti-spike trimerni IgG, 1426,0 (IQR, 742,0$2698,6)$ za anti-spike RBS IgG i 290,2 (IQR, 12,5-32,1) za anti-spike S1 lgA. Značajno obrnuta povezanost je nađena između godina i i ukupnog povećanja anti-spike trimernog $\lg G(r=-0,24 ; p=0,001)$ i anti-spike S1 $\lg A(r=0,16 ; p$ $=-0,028)$ ali ne $i$ sa anti-spike RBD $\lg G(r=0,05 ; p=$ 0,497).

Zaključak: mRNA COVID-19 vakcinacija dovodi do povećanja nivoa u serumu anti-spike trimernog $\lg A$ i RBD lgG, kao i do značajnog povećanja u serumu anti-spike S1 $\lg A$.

Ključne reči: COVID-19, vakcinacija, imuni odgovor, antitela, $\lg A$

mediators, to kill the pathogen and/or the infected host cells (cellular immunity), as well as forming the so-called memory cells, which could be effective to contrast recurrent or repeated infections caused by the same pathogen.

The current generation of COVID-19 vaccines encompass four major formulations, including lipidbased mRNA-lipid nanoparticles vaccines (mRNALNPs), vector (mostly adenovirus-based) DNA vaccines, attenuated or inactivated viruses, along with protein-based subunit vaccines (6). Compared to other types of vaccines currently approved for use in humans, mRNA-LNPs vaccines have several advantages such as their natural ability to reproduce the infection without deliverance of viable viral particles (i.e., the mRNA is delivered into the host cells, where is translated into antigen viral proteins), the potentially lower immunogenicity and cytotoxicity, the possibility to contain multimeric antigens (so enabling rapid reengineering), the lower need for adjuvants for boosting the immune response, along with the greater potential to be manufactured quickly, at higher volumes and lower costs (7). These favorable characteristics have paved the way to rapid and massive commercialization of mRNA-LNPs, which are now available worldwide for human use in two brands, marketed by Pfizer (COVID-19 mRNA vaccine BNT162b2; Comirnaty) and Moderna (COVID-19 mRNA vaccine mRNA-1273; Moderna COVID 19 Vaccine).

Several lines of evidence now concur to attest that the ongoing vaccination campaign is associated with high protection against development of severe COVID-19 illness (i.e., between $90-100 \%$ reduction for the two mRNA-LNPs), and moreover, may also be effective at decreasing viral circulation, by reducing the risk of SARS-CoV-2 infection in vaccinated individuals (i.e., 94-95\% lower for the two mRNA-LNPs) 
(8). The substantial reduction in the risk of developing severe COVID-19 illness after vaccination seems mostly attributable to development of circulating neutralizing antibodies, mostly of the IgG class, which specifically target the spike protein of SARS-CoV-2, its S1 subunit or its receptor binding domain (RBD), and thereby limit or completely abolish the binding with host natural viral receptors (i.e., mostly ACE2) (9). Unlike this well-established mechanism, prevention of SARS-CoV-2 infection seems instead attributable to mucosal immunity, which is essentially based on the presence of primed immune cells and secretory antibodies of the $\lg A$ and $\lg G$ class, which would be effective to rapidly neutralize the virus at the mucosal surface, thus impeding or completely abolishing host penetration and spread to target organs (10). With the exception of a few preliminary case series and reports, characterized by relatively limited sample sizes (11-13), most studies that have explored, deciphered and monitored the immune response developed after COVID-19 vaccination have almost solely focused on assaying serum $\lg G$ antibodies and systemic cell-mediated immunity (14), thus discounting the potential role that neutralizing $\lg A$ antibodies would play in limiting viral spread in the community and thereby facilitating the achievement of herd immunity.

This study was hence aimed at assessing the humoral immune response developing after mRNA COVID-19 vaccination in a sample of baseline SARSCoV-2 seronegative healthcare workers, with assessment of antibodies of both $\lg G$ and $\lg A$ classes, targeting the entire SARS-CoV-2 Spike protein trimer (anti-spike trimeric $\operatorname{lgG}$ ), the RBD (anti-spike RBD $\operatorname{lgG}$ ) or the S1 subunit (anti-spike S1 $\lg A$ ), and thus reliably reflecting the neutralizing antibodies potential developing after vaccination.

\section{Materials and Methods}

\section{Study population}

Our study population consisted of a cohort of SARS-CoV-2 seronegative healthcare workers of the Pederzoli Hospital of Peschiera del Garda (Verona,
Italy), who voluntary accepted to be vaccinated with the mRNA-LNPs COVID-19 vaccine BNT162b2 (Comirnaty; Pfizer-BioNTech, NY, USA). Baseline seronegativity was confirmed the day before vaccination via routine monitoring with a Roche Elecsys AntiSARS-CoV-2 S immunoassay, performed on a Roche Cobas 6000 (Roche Diagnostics, Basel, Switzerland; seronegativity defined as having anti-SARS-CoV-2 S total antibodies levels $<0.8 \mathrm{U} / \mathrm{L}$ ). A first dose of 30 $\mu \mathrm{g}$ of vaccine was administered between January 4 and 7,2021 , which was then followed by the second dose of $30 \mu \mathrm{g}$ vaccine administered exactly 3 weeks after the first. All vaccines were prepared following manufacturer's recommendations and administered within $30 \mathrm{~min}$ from preparation. None of the subjects included in this study were taking immunosuppressive agents before vaccination. All subjects who participated in this retrospective observational study provided two separate written informed consents for being vaccinated and for inclusion in the post-vaccination antiSARS-CoV-2 survey. This retrospective observational study was conducted in accordance with the Declaration of Helsinki and its protocol was cleared by the Ethics Committee of the Provinces of Verona and Rovigo (3246CESC).

\section{Blood sampling and laboratory testing}

Venous blood was collected by venipuncture within evacuated blood tubes with clot activator and gel (Greiner Bio-One, Kremsmünster, Austria) at three different time points, i.e., just before the administration of the first vaccine dose, at 21 days (just before the administration of the second vaccine dose) and, finally, 50 days after the first vaccine dose (i.e., 1 month after the second vaccine dose). Serum was separated from blood cells by centrifugation at $1500 \times \mathrm{g}$ for $15 \mathrm{~min}$ at room temperature and separated in two identical aliquots of approximately 1.5 $\mathrm{mL}$, which were keep stored at $-70{ }^{\circ} \mathrm{C}$ until all measurements were performed. The three paired aliquots collected at the three different time points from each participant were concomitantly thawed, re-centrifuged and tested with three different anti-SARSCoV-2 immunoassays, as summarized in Table $I$.

Table I Technical characteristics of the anti-SARS-CoV-2 antibodies immunoassays used in this study.

\begin{tabular}{|l|c|c|c|c|c|c|}
\hline Immunoassay & Company & Analyzer & Principle & Antibodies & Target & Cut-off \\
\hline $\begin{array}{l}\text { LIAISON SARS-CoV-2 } \\
\text { TrimericS IgG }\end{array}$ & DiaSorin & LIAISON XL & CLIA & IgG & $\begin{array}{c}\text { Spike protein } \\
\text { trimer }\end{array}$ & $<33.8$ BAU/mL \\
\hline $\begin{array}{l}\text { ACCESS SARS-CoV-2 } \\
\text { IgG II }\end{array}$ & Beckman Coulter & Access 2 & CLIA & IgG & RBD & $<10$ AU/mL \\
\hline $\begin{array}{l}\text { Anti-SARS-CoV-2 } \\
\text { ELISA IgA }\end{array}$ & Euroimmun & - & Manual ELISA & IgA & S1 & $<1.1 \mathrm{ratio}$ \\
\hline
\end{tabular}

$\mathrm{AU}$, arbitrary units; BAU, binding antibody units; CLIA, ChemiLuminescent ImmunoAssay; Ig, ELISA; enzyme linked immunoassay; Ig, Immunoglobulin; RBD, Receptor Binding Domain; S1, Spike protein S1 subunit 
These included the assessment of anti-spike trimeric IgG, anti-spike RBD IgG and anti-spike S1 subunit IgA. All three assays were performed in accordance with manufacturer's recommendations.

\section{Statistical analysis}

The results of the three anti-SARS-CoV-2 immunoassays are presented as median and interquartile range (IQR), or as ratio with baseline anti-SARS-CoV-2 antibodies value (i.e., (21 or 50 days time point value)/ (baseline value and/or limit of detection)). Spearman's test was used to assess correlations between the results of anti-SARS-CoV-2 immunoassays or patient characteristics. The statistical analysis was performed using Analyse-it (Analyseit Software Ltd, Leeds, UK).

\section{Results}

The final study population consisted of 181 SARS-CoV-2 seronegative healthcare workers (median age 42 years, IQR 31-52 years; 108 women, $59.7 \% ; 7$ subjects $>65$ years, $3.9 \%$ ). The kinetics of anti-SARS-CoV-2 antibodies development after Pfizer Comirnaty vaccination is summarized in Table $/ /$ and Figure 1. Vaccine administration was effective to elicit sustained production of all anti-SARS-CoV-2 antibodies classes. Before administration of the second vaccine dose, positivization occurred for $98.3 \%, 92.8 \%$ and $81.8 \%$ cases for anti-spike trimeric lgG, antispike RBD IgG and anti-spike S1 IgA, respectively. Such percentages increased to $100 \%$ for both antispike trimeric lgG and anti-spike RBD lgG 30 days after the second vaccine dose, whilst $1.7 \%$ of subjects remained anti-spike S1 IgA negative.

The median increase (ratio) of the different classes of anti-SARS-CoV-2 antibodies elicited by the two Pfizer Comirnaty vaccine doses is shown in Figure 2. In summary, the first vaccine dose triggered a median increase from baseline of 103.3 (IQR, 58.2147.3) folds for anti-spike trimeric IgG, 210.9 (IQR, 90.4-469.5) folds for anti-spike RBD IgG, and 13.3 (IQR, 6.5-25.0) folds for anti-spike S1 IgA, whilst the second vaccine dose elicited a median increase from baseline of 576.1 (IQR, 360.7-867.8) folds for antispike trimeric IgG, 1426.0 (IQR, 742.0-2698.6) folds for anti-spike RBD IgG, and 20.2 (IQR, 12.532.1) folds for anti-spike S1 lgA. Therefore, compared to the anti-SARS-CoV-2 values attained with the first vaccine dose, the second boost triggered a further modest median increase of these antibodies, being 6.3 (IQR, 4.4-9.5) folds for anti-spike trimeric IgG, 7.2 (IQR, 4.4-11.2) folds for anti-spike RBD IgG, and 1.5 (IQR, 1.1-2.3) folds for anti-spike S1 IgA, respectively. The inter-individual variation (expressed as coefficient of variation; CV\%) of antiSARS-CoV-2 antibodies levels achieved after the first and second vaccine dose was considerably broad, being $70.6 \%$ and $65.2 \%$ for anti-spike trimeric $\operatorname{lgG}$, $81.2 \%$ and $62.0 \%$ for anti-spike RBD $\operatorname{lgG}$, and $71.6 \%$ and $66.9 \%$ for anti-spike S1 IgA, respectively.

Significant Spearman's correlations were found between the ratios of antibodies levels from baseline up to end of the second cycle of vaccination (i.e., 50 days after the first dose), as follows: anti-spike trimeric IgG vs. anti-spike RBD lgG: $r=0.60(95 \% \mathrm{Cl}, 0.50$ $0.68 ; \mathrm{p}<0.001)$; anti-spike trimeric lgG vs. anti-spike S1 IgA: $r=0.22(95 \% \mathrm{Cl}, 0.08-0.36 ; \mathrm{p}=0.003)$, and anti-spike RBD IgG vs. anti-spike S1 IgA: $r=0.25$ $(95 \% \mathrm{Cl}, 0.11-0.38 ; \mathrm{p}<0.001)$ (Figure 3). Notably, a significant inverse association was also found between age and cumulative increase (50 days/baseline ratio) of anti-spike trimeric $\operatorname{lgG}(\mathrm{r}=-0.24 ; 95 \% \mathrm{Cl}$, -0.37 to $-0.10 ; p=0.001)$ and anti-spike $\mathrm{S} 1 \mathrm{lgA}(\mathrm{r}=-$ $0.16 ; 95 \% \mathrm{Cl},-0.30$ to $-0.02 ; p=0.028)$, but not with anti-spike RBD $\operatorname{lgG}(r=-0.05 ; 95 \% \mathrm{Cl},-0.20$ to $0.10 ; p=0.497$ ), whilst no significant correlation was found between sex and test results any of the three immunoassays (all $\mathrm{p}>0.05$ ).

Table II Kinetics of anti-SARS-CoV-2 antibodies development after Pfizer Comirnaty vaccination.

\begin{tabular}{|c|c|c|c|}
\hline Antibodies & Baseline & 21 days & 50 days \\
\hline \multicolumn{4}{|l|}{ Anti-spike trimeric lgG } \\
\hline - Serum values (BAU/mL) & $<4.8$ & $504.4(280.8-770.5)$ & 2834 (1740.3-4576.0) \\
\hline$-<$ cut-off $(n ; \%)$ & $181 / 181(100 \%)$ & $178 / 181(1.7 \%)$ & 0/181 (0\%) \\
\hline \multicolumn{4}{|l|}{ Anti-spike RBD lgG } \\
\hline - Serum values (AU/mL) & $0.21(0.12-0.39)$ & $52.3(26.0-92.7)$ & $350.6(218.3-543.2)$ \\
\hline$-<$ cut-off (n; \%) & 181/181 (100\%) & $168 / 181(7.2 \%)$ & 0/181 (0\%) \\
\hline \multicolumn{4}{|l|}{ Anti-spike S1 lgA } \\
\hline - Serum values (ratio) & $0.19(0.15-0.27)$ & $3.06(1.49-4.62)$ & $4.55(2.89-5.94)$ \\
\hline$-<$ cut-off $(n ; \%)$ & $181 / 181(100 \%)$ & 148/181 (18.2\%) & 178/181 (1.7\%) \\
\hline
\end{tabular}

$\mathrm{AU}$, arbitrary units; BAU, binding antibody units; Ig, Immunoglobulin; RBD, Receptor Binding Domain; S1, Spike protein S1 subunit 


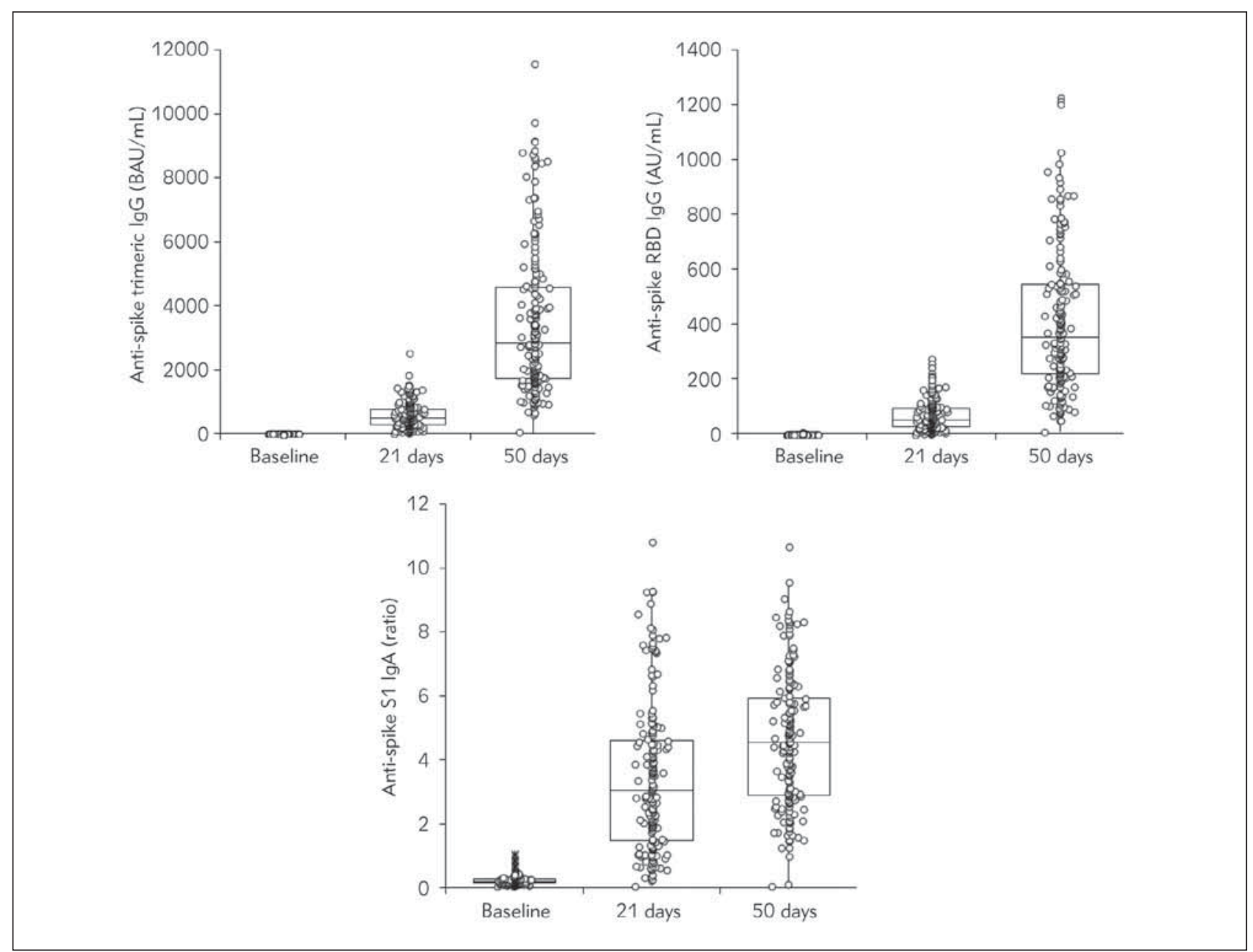

Figure 1 Kinetics of anti-SARS-CoV-2 antibodies development after Pfizer Comirnaty mRNA vaccination.

Ig, Immunoglobulin; RBD, Receptor Binding Domain; S1, Spike protein S1 subunit

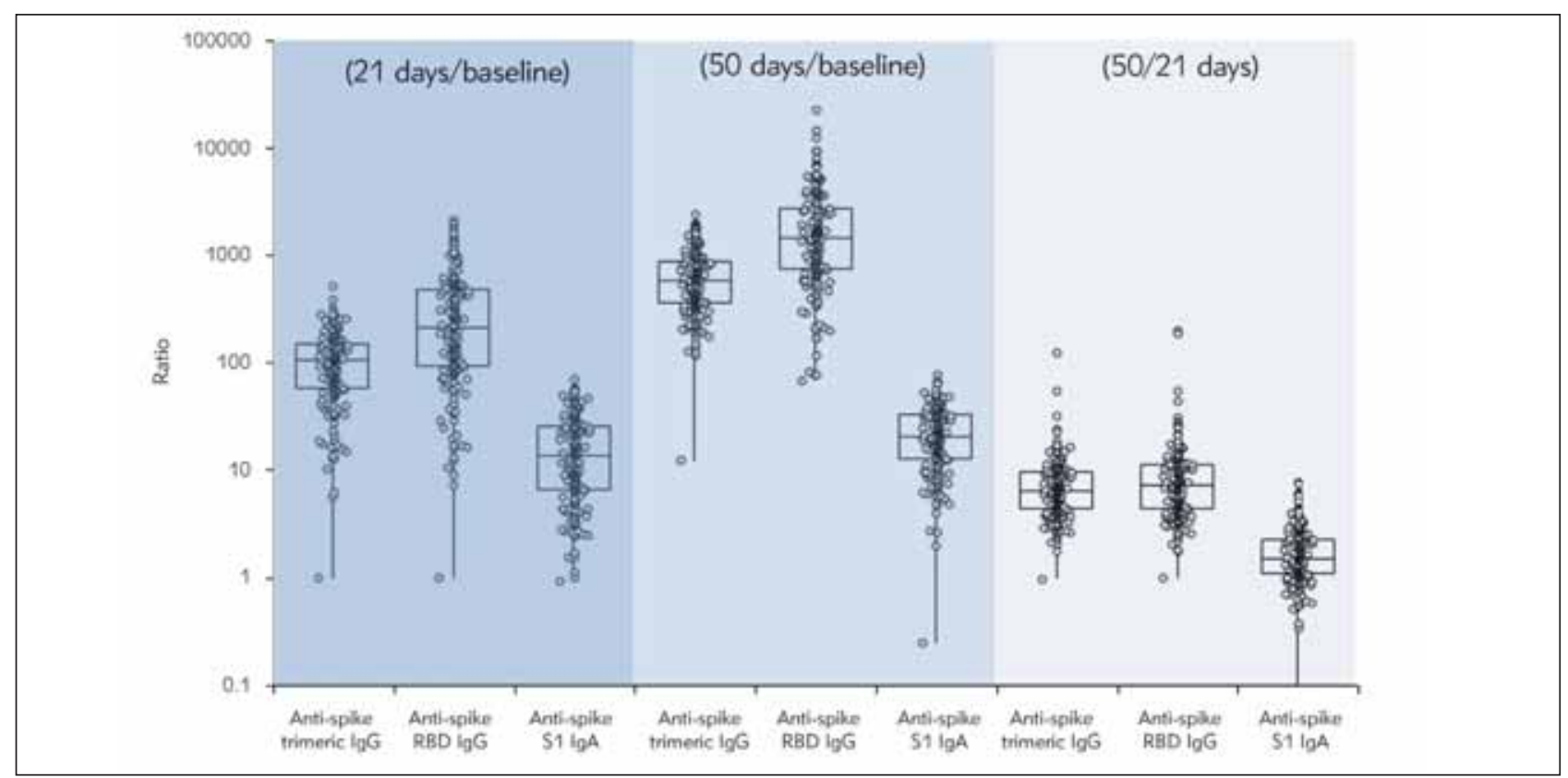

Figure 2 Median increase (ratio) of the different classes of anti-SARS-CoV-2 antibodies elicited by the two Pfizer Comirnaty mRNA vaccine doses.

Ig, Immunoglobulin; RBD, Receptor Binding Domain; S1, Spike protein S1 subunit 


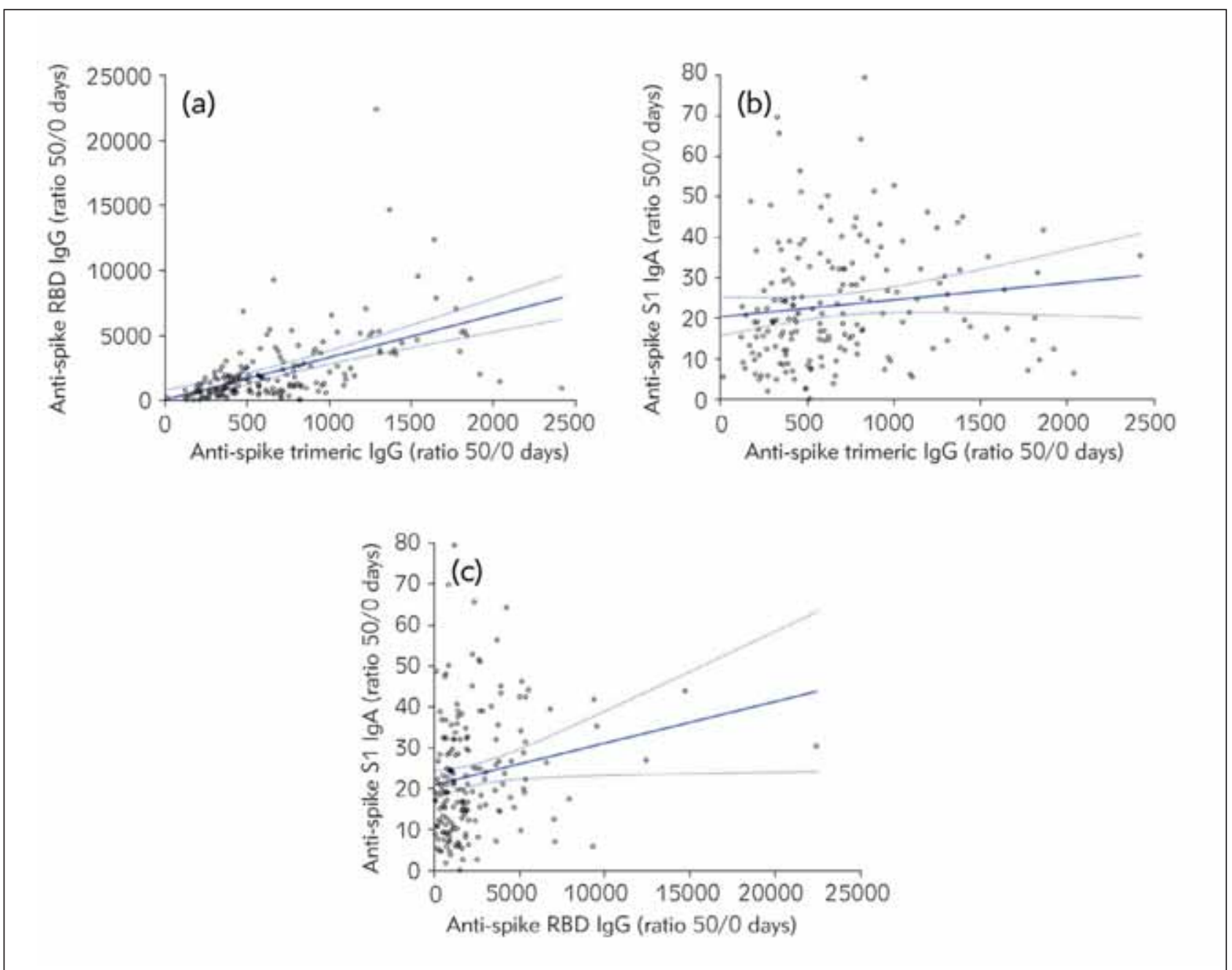

Figure 3 Spearman's correlation between the overall serum increase of anti-spike trimeric lgG, anti-spike RBD lgG and antispike S1 IgA elicited after administration of two Pfizer Comirnaty mRNA vaccine doses. The Spearman's correlation coefficients were as follows: anti-spike trimeric IgG vs. anti-spike RBD lgG: $r=0.60$ (95\% Cl, 0.50-0.68; $p<0.001)$ (Figure 3a); anti-spike trimeric lgG vs. anti-spike S1 lgA: $r=0.22(95 \% \mathrm{Cl}, 0.08-0.36 ; \mathrm{p}=0.003)$ (Figure $3 \mathrm{~b}$ ), and anti-spike RBD lgG vs. anti-spike S1 lgA: $r=0.25(95 \% \mathrm{Cl}, 0.11-0.38 ; \mathrm{p}<0.001)$ (Figure 3c).

$\mathrm{Ig}$, Immunoglobulin; RBD, Receptor Binding Domain; S1, Spike protein S1 subunit

\section{Discussion}

With COVID-19 still causing several thousands of deaths every day around the globe, universal equitable access to COVID-19 vaccination seems the key for attenuating the dramatic health, social and economic impact of this ongoing SARS-CoV-2 pandemic outbreak (15). Preliminary epidemiologic evidence seemingly attests that there is a straightforward association between vaccine distribution and reduction of SARS-CoV-2 positive cases, COVID-19 hospitalizations and deaths (16). Although it is virtually undeniable that cellular immunity and circulating anti-SARSCoV-2 IgG antibodies would act in synergy to neutralize the virus either within or outside the host cells (9), mucosal immune response is expected to play a major role in preventing or limiting viral infection, as SARS-CoV-2 initially penetrates the cells of upper and lower respiratory tracts (10). To this end, the associations between nasal anti-SARS-CoV-2 IgA antibodies responses, virus neutralization at the mucosal surface, and lower risk of developing severe COVID-19 illness provide further support to the clinical significance of assessing and monitoring mucosal immunity in patients with natural SARS-CoV-2 infection and/or in COVID-19 vaccine recipients $(17,18)$.

Several lines of evidence now attest that the $\lg A$ serum levels quite accurately reflect the concentration of these immunoglobulins at the mucosal surface, and especially that mucosal anti-SARS-CoV-2 spike protein IgA levels strongly correlate with virus neutralization potency $(19,20)$. As concerns the former aspect, the cumulative seropositivity rate of $\lg A$ antibodies targeting the RBD of SARS-CoV-2 is comparable to that of the $\lg$ class, and consistently higher 
than that of $\lg M$ antibodies (21). Pisanic and colleagues (22) reported that matched serum and saliva anti-SARS-CoV-2 lgA levels measured with many different methods were significantly correlated in patients with COVID-19. A significant correlation between serum and secretory anti-SARS-CoV-2 spike protein $\lg A(r=0.542 ; p<0.001)$ and RBD $\lg A$ $(r=0.389 ; p<0.001)$ has also been reported in COVID-19 patients by Isho and colleagues (23). These findings would hence convincingly support the hypothesis that serum assessment of anti-SARS-CoV2 neutralizing antibodies may reliably mirror their secretory counterpart, thus reflecting virus neutralizing potential at the mucosal surface.

With respect to the role played by anti-SARSCoV-2 IgA antibodies in preventing viral infection, Sterlin et al. (21) showed that the early neutralizing antibody potential seems to be predominated by antibodies of the $\mathrm{lgA}$ class, whose appearance is comparable to that of lgG antibodies, but seems significantly earlier than that of antibodies of the $\lg M$ class. Importantly, the presence of anti-SARS-CoV-2 RBD $\lg A$ in saliva appeared to be strongly correlated with their neutralizing potency. A highly significant correlation between the serum $\operatorname{lgA}$ titer and that of antiSARS-CoV-2 neutralizing antibodies has also been demonstrated by Varnait et al. (24), thus confirming that this class of secretory immunoglobulins may be really effective to neutralize the virus at mucosal surface. Importantly, Quinti et al. (25) recently underlined that special consideration should be given to the fact that the risk of being infected by SARS-CoV-2, developing severe COVID-19 illness or displaying prolonged viral shedding, as well as that of experimenting vaccination failure, may be especially magnified in subjects with insufficient serum and/or secretory anti-SARS-CoV-2 IgA response.

As concerns the specific post-vaccination kinetics of serum neutralizing $\lg \mathrm{A}$ antibodies compared to that of $\mathrm{lgG}$, our data showed that Pfizer COVID-19 mRNA vaccine administration elicited a very sustained response of anti-spike trimeric lgG (576-fold from baseline) and anti-spike RBD lgG (1426-fold from baseline), whilst the increase of anti-spike S1 IgA was apparently weaker (around 20-fold from baseline), yet detectable and likely of clinical significance. Notably, the first vaccine dose left a considerable number of recipients with negative anti-spike S1 IgA levels (i.e., approximately 18\%), whilst the rate of non-responders to the mRNA vaccine decreased to $<2 \%$ after the second dose (i.e., 3 subjects, two men aged 40 and 58 years, and one women aged 52 years - studies are ongoing to identify the possible reasons). This is congruent with real-life data on the relatively lower efficacy of administering a single
mRNA vaccine dose, since vaccine efficiency for preventing SARS-CoV-2 infection was shown to increase from around $46 \%$ between 14-20 days after the first vaccine dose, up to $92 \%$ more than 7 days after the second vaccine dose (26). Moreover, vaccine efficacy for preventing COVID-19 symptomatic illness was significantly increased after the second dose (i.e., $57 \%$ to $94 \%$ ), with a similar but more marginal effect on hospitalizations (i.e., 74\% to 87\%) (26). Taken together, this data strongly suggests that the lower anti-SARS-CoV-2 neutralizing IgA antibodies response observed in our study after a single mRNA vaccine dose would actually mirror a still insufficient mucosal protection against SARS-CoV-2, thus corroborating current beliefs that the second mRNA vaccine dose is essential for achieving a sufficient level of herd immunity (27), which may hence at least partially develop through an adequate increase of serum and mucosal levels of anti-SARS-CoV-2 lgA neutralizing antibodies. Another important aspect that has emerged from our study, is that the relative increase from baseline of anti-spike S1 IgA levels was inversely correlated with age, as it was the increase of antispike trimeric lgG, so that consideration shall be given to more strictly monitoring both antibodies classes in older people and eventually define a personalized vaccination program (i.e., using a third booster).

In conclusion, the results of our study attest that mRNA COVID-19 vaccination is effective to elicit sustained levels of serum anti-spike trimeric $\operatorname{lgG}$ and anti-spike RBD lgG, while also modestly but significantly increasing those of serum anti-spike S1 IgA.

\section{Research funding: None declared.}

Author contributions: All authors have accepted responsibility for the entire content of this manuscript and approved its submission.

Informed consent: Informed consent was obtained from all individuals included in this study.

Ethical approval: The study was cleared by the Ethics Committee of the Provinces of Verona and Rovigo (3246CESC).

\section{Conflict of interest statement}

All the authors declare that they have no conflict of interest in this work. 


\section{References}

1. Lippi G, Sanchis-Gomar F, Henry BM. Coronavirus disease 2019 (COVID-19): the portrait of a perfect storm. Ann Transl Med 2020; 8: 497.

2. Delikhoon M, Guzman MI, Nabizadeh R, Norouzian Baghani A. Modes of Transmission of Severe Acute Respiratory Syndrome-Coronavirus-2 (SARS-CoV-2) and Factors Influencing on the Airborne Transmission: A Review. Int J Environ Res Public Health 2021; 18: 395.

3. Lotfi M, Hamblin MR, Rezaei N. COVID-19: Transmission, prevention, and potential therapeutic opportunities. Clin Chim Acta 2020 Sep; 508: 254-66.

4. Szkaradkiewicz-Karpińska AK, Szkaradkiewicz A. Towards a more effective strategy for COVID-19 prevention (Review). Exp Ther Med 2021; 21: 33.

5. World Health Organization. Vaccines and immunization: What is vaccination? Available at: https://www.who.int/ news-room/q-a-detail/vaccines-and-immunization-whatis-vaccination. Last accessed, May 24, 2021.

6. Fauci, A.S. The story behind COVID-19 vaccines. Science 2021; 372: 109.

7. Wu Z, Li T. Nanoparticle-Mediated Cytoplasmic Delivery of Messenger RNA Vaccines: Challenges and Future Perspectives. Pharm Res 2021; 38: 473-8.

8. Abdool Karim SS, de Oliveira T. New SARS-CoV-2 Variants - Clinical, Public Health, and Vaccine Implications. N Engl J Med 2021; 384: 1866-8.

9. Xiaojie S, Yu L, Lei Y, Guang Y, Min Q. Neutralizing antibodies targeting SARS-CoV-2 spike protein. Stem Cell Res 2020 Dec 15; 50:102125. Doi: 10.1016/j.scr. 2020.102125. Epub ahead of print.

10. Ahnach M, Zbiri S, Nejjari S, Ousti F, Elkettani C. C-reactive protein as an early predictor of COVID-19 severity. J Med Biochem 2020: 39 (4): 500-7.

11. Wang Z, Schmidt F, Weisblum Y, Muecksch F, Barnes CO, Finkin $S$, et al. mRNA vaccine-elicited antibodies to SARS-CoV-2 and circulating variants. Nature 2021; 592: 616-22.

12. Ketas TJ, Chaturbhuj D, Cruz-Portillo VM, Francomano E, Golden E, Chandrasekhar S, et al. Antibody responses to SARS-CoV-2 mRNA vaccines are detectable in saliva. bioRxiv [Preprint]. 2021 Mar 11:2021.03.11.434841. Doi: 10.1101/2021.03.11.434841.

13. Danese E, Montagnana M, Salvagno GL, Peserico D, Pighi L, De Nitto S, et al. Comprehensive assessment of humoral response after Pfizer BNT162b2 mRNA Covid19 vaccination: a three-case series. Clin Chem Lab Med 2021 Apr 12. Doi: 10.1515/cclm-2021-0339. Epub ahead of print.

14. McDonald I, Murray SM, Reynolds CJ, Altmann DM, Boyton RJ. Comparative systematic review and metaanalysis of reactogenicity, immunogenicity and efficacy of vaccines against SARS-CoV-2. NPJ Vaccines 2021; 6: 74.

15. The Lancet Infectious Diseases. The rocky road to universal COVID-19 vaccination. Lancet Infect Dis 2021 May 14:S1473-3099(21)00275-9. Doi: 10.1016/S14733099(21)00275-9. Epub ahead of print.
16. Borchering RK, Viboud C, Howerton E, Smith CP, Truelove S, Runge MC et al. Modeling of Future COVID19 Cases, Hospitalizations, and Deaths, by Vaccination Rates and Nonpharmaceutical Intervention Scenarios United States, April-September 2021. MMWR Morb Mortal Wkly Rep 2021; 70: 719-24.

17. Butler SE, Crowley AR, Natarajan $H, X u S$, Weiner JA, Bobak CA, et al. Distinct Features and Functions of Systemic and Mucosal Humoral Immunity Among SARSCoV-2 Convalescent Individuals. Front Immunol 2021; 11: 618685 .

18. Lippi G, Sciacovelli L, Trenti T, Plebani M. Kinetics and biological characteristics of humoral response developing after SARS-CoV-2 infection: implications for vaccination. Clin Chem Lab Med 2021 Jan 21. Doi: 10.1515/cclm2021-0038. Epub ahead of print.

19. Ejemel M, Li Q, Hou S, Schiller ZA, Tree JA, Wallace A, et al. A cross-reactive human IgA monoclonal antibody blocks SARS-CoV-2 spike-ACE2 interaction. Nat Commun 2020; 11: 4198.

20. Lippi G, Mattiuzzi C. Clinical value of anti-SARS-COV-2 serum IgA titration in patients with COVID-19. J Med Virol 2021; 93: 1210-1.

21. Sterlin D, Mathian A, Miyara M, Mohr A, Anna F, Claër L, et al. IgA dominates the early neutralizing antibody response to SARS-CoV-2. Sci Transl Med 2021; 13:eabd2223.

22. Pisanic N, Randad PR, Kruczynski K, Manabe YC, Thomas DL, Pekosz A, et al. COVID-19 Serology at Population Scale: SARS-CoV-2-Specific Antibody Responses in Saliva. J Clin Microbiol 2020; 59:e02204-20.

23. Isho B, Abe KT, Zuo M, Jamal AJ, Rathod B, Wang JH, et al. Persistence of serum and saliva antibody responses to SARS-CoV-2 spike antigens in COVID-19 patients. Sci Immunol 2020; 5:eabe5511.

24. Varnait R, García M, Glans H, Maleki KT, Sandberg JT, Tynell J, et al. Expansion of SARS-CoV-2-Specific Antibody-Secreting Cells and Generation of Neutralizing Antibodies in Hospitalized COVID-19 Patients. J Immunol 2020; 205: 2437-46.

25. Quinti I, Mortari EP, Fernandez Salinas A, Milito C, Carsetti R. IgA Antibodies and IgA Deficiency in SARSCoV-2 Infection. Front Cell Infect Microbiol 2021; 11:655896.

26. Dagan N, Barda N, Kepten E, Miron O, Perchik S, Katz MA, et al. BNT162b2 mRNA Covid-19 Vaccine in a Nationwide Mass Vaccination Setting. N Engl J Med 2021; 384: 1412-23.

27. Stanković B, Kotur N, Gašić V, Klaassen K, Ristivojeić B, Stojiljković M, Pavlović S, Zukić B. Pharmacogenomics landscape of COVID-19 therapy response in Serbian population and comparison with worldwide populations. J Med Biochem 2020; 39(4) 488-99. 